\title{
AN EXTENSION OF THE HILBERT-TYPE INEQUALITY AND ITS REVERSE
}

\author{
BICHENG YANG
}

Abstract. By introducing some parameters and the weight coefficient, one proves a new extension of the Hilbert-type inequality with a best constant factor. The reverse, some equivalent forms and a number of new particular cases are considered.

Mathematics subject classification (2000): 26D15.

Key words and phrases: Hilbert-type inequality, weight coefficient, Hölder's inequality, reverse.

\section{REFERENCES}

[1] G. H. Hardy, J. E. LitTlewood And G. Polya, Inequalities, Cambridge Univ. Press, Cambridge, 1952.

[2] D. S. Mitrinović, J. E. PEČARIĆ AND A. M. FInK, Inequalities involving functions and their integrals and derivertives, Kluwer Academic Publishers, Boston, 1991.

[3] G. H. HARDY, Note on a theorem of Hilbert concerning series of positive terms, Proc. London Math. Soc., 23, 2(1925), Records of Proc. xlv-xlvi.

[4] Bicheng YANG AND Mingzhe GaO, On a best value of Hardy-Hilbert's inequality. Advances in Math., 26, 2(1997): 159-164.

[5] Bicheng YANG, On new generalization of Hilbert's inequality, J. Math. Anal. Appl., 248(2000): 29-40.

[6] Bicheng Yang And L. Debnath, On the extended Hardy-Hilbert's inequality, J. Math. Anal. Appl., 272(2002): 187-199.

[7] I. BRnETIĆ AND J. PEČARIĆ, Generalization of inequalities of Hardy-Hilbert type, Math. Ineq. Appl., 7, 2(2004): 217-225.

[8] I. Brnetić, Mario Krnić And J. PeČArić, Multiple Hilbert and Hardy-Hilbert inequalities with non-conjugate parameters, Bull. Austral., Math. Soc., 71(2005): 447-457.

[9] BICHENG YANG AND TH. M. RASSIAS, On the way of weight coefficient and research for the Hilbert-type inequalities, Math. Ineq. Appl., 6, 4(2003): 625-658.

[10] BICHENG YANG, On best extensions of Hardy-Hilbert's inequality with two parameters, J. Ineq. Pure Appl. Math., 6, 3(2005): Art. 81.

[11] BICHENG YANG, A reverse Hardy-Hilbert's integral inequality, J. Jilin Univ. (Science), 42, 4(2004): 489-493.

[12] BICHEng YAnG, A reverse of the Hardy-Hilbert's type inequality, J. Southwest China Normal Univ. (Natural Science), 30, 6(2005): 1012-1015.

[13] BICHENG YANG, On a more accurate Hardy-Hilbert's type inequality and its applications, Acta Math. Sinica, 49, 2(2006): 363-368.

[14] Jichang KuANG, Applied inequalities, Shangdong Science Press, Jinan, 2004.

[15] BICHENG YANG, Generalization of Hilbert's type inequality with best constant factor and its applications, J. Math. Res. Exp., 25, 2(2005): 341-346. 